\title{
Diverse Chromosomal Anomalies in a Family*
}

\author{
LEONARD ATKINS, CHRISTOS S. BARTSOCAS, and PHILIP J. PORTER \\ From the Departments of Pathology and Pediatrics, Harvard Medical School, and the fames Homer Wright Pathology \\ Laboratories, the Children's Service, the foseph P. Kennedy, Fr. Memorial Laboratories of the Neurology Service, \\ Massachusetts General Hospital, Boston, Massachusetts; and the Children's Developmental Clinic, \\ Cambridge, Massachusetts, U.S.A.
}

The occurrence of diverse chromosomal anomalies within one family has been well documented (Barnicot, Ellis, and Penrose, 1963; Benirschke et al., 1962; Gustavson, Atkins, and Patricks, 1964; Hamerton, Giannelli, and Carter, 1963; Hauschka et al., 1962; Hustinx, 1966; Johnston and Petrakis, 1963; Lejeune et al., 1963; Miller et al., 1961; Therman et al., 1961; Wright et al., 1963; Zergollern et al., 1964; Brown et al., 1967).

In this report a Negro family with an unusual combination of chromosomal anomalies is described. The propositus was a trisomy-21 mongoloid, with a paternally-inherited $D / D$ translocation. A sib was shown to have an XXXXY sex chromosome constitution.

\section{Case Reports}

The propositus, a 4-year-old boy, was brought to the Clinics because of poor speech development. He was the product of an uncomplicated pregnancy and a fullterm normal delivery, birthweight $3.01 \mathrm{~kg}$. and length $48.3 \mathrm{~cm}$. An umbilical hernia was repaired at the age of 2 years. There were no other problems except that the developmental milestones were retarded. He was able to sit up at 9 months, to stand at 12 to 15 months, and to walk at 18 months. Physical examination showed a fairly active, well-nourished 4-year-old child, weight $17 \cdot 3 \mathrm{~kg}$. (above 50 th centile), length $101 \mathrm{~cm}$. (25th centile), and head circumference $50.8 \mathrm{~cm}$. (above 50 th centile). He could only say a few words that his mother understood. The eyes were wide spaced, with epicanthal folds and mongoloid slants; the irides and fundi were normal. The fifth fingers were short and incurved, and there was wide separation of the first and second toe bilaterally. The heart sounds were normal and no murmurs were audible. There were no palmar simian creases, but the axial triradii were distal. The clinical diagnosis was Down's syndrome.

Received February 15, 1968

* Supported by Children's Bureau Project No. 906, and United States Public Health Service Training Grant No. 5-TI HD 33-10.
There were 2 other sibs, both male. A younger brother was 8 months old and the product of a 40-week gestation, birthweight $1.82 \mathrm{~kg}$. Physical examination $\dot{\omega}$ revealed a small well-nourished infant weighing $6.8 \mathrm{~kg}$. $\vec{A}$ (below the 10th centile), with a length of $62.2 \mathrm{~cm}$. 우 (below the 10th centile) and a head circumference of $43.2 \mathrm{~cm}$., equivalent to that of a 6-month-old infant. He could roll over, but he could not sit by himself. $\mathbb{D}$ There were hypertelorism, strabismus, bilateral epican- $\mathbb{\Phi}$ thal folds, and slight antimongoloid slanting of the eyes. There was a high-arched palate. The heart was normal. $\stackrel{\Phi}{-}$ The nipples were widely spaced. An umbilical hernia $\vec{\bullet}$ was present. No palmar simian creases were noted $\mathscr{O}$ The penis was small with a normal urethral opening, the testes were undescended, and the scrotum appeare normal. Radiological examination of the elbows was negative, with no evidence of radio-ulnar synostosis.

An older brother, aged 6, showed normal physical and psychomotor development.

The father, who was 31, was born in Barbados and was phenotypically normal. His sister had had 2 spontaneous abortions and a phenotypically normal daughter. The mother of the index case was 40 and appeared normal. She gave no history of any other pregnancies or miscarriages. There was no family history of mental retardation or of congenital abnormalities.

\section{Cytogenetic Findings}

The chromosomes of both parents and the three children were studied in leucocytes cultured by a modification of the method of Moorhead et al. (1960). The chromosome counts are summarized in Table I. All cells of the propositus contained 46 chromosomes with of trisomy in the $\mathrm{G}$ group (21-22). In addition, there were only 4 normal members of the $D$ group (13-15). In place of 2 large acrocentric chromosomes there was an $\mathrm{W}$ odd metacentric chromosome comparable in size to a No. 3 which was interpreted as a $D / D$ translocation since 6 the remainder of the karyotype, with the exception of the trisomy in the G group, appeared to be normal (Fig. 1).

The modal number of the younger sib was 49, with 3 additional chromosomes in the $\mathrm{C}$ group (6-X-12). In 


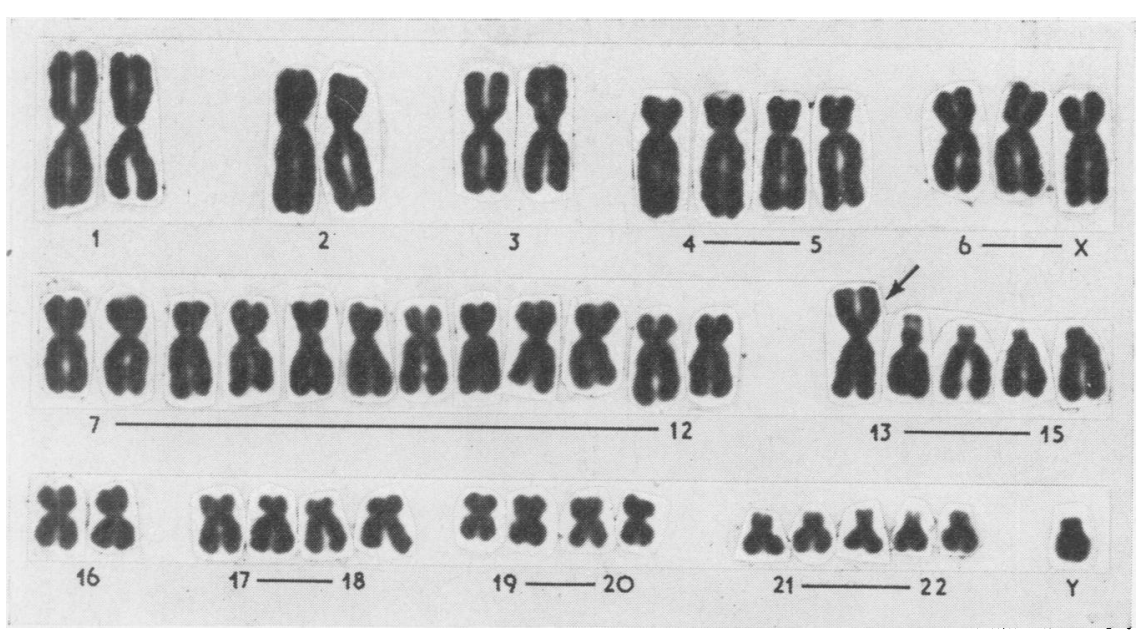

Fig. 1. Karyotype of the propositus showing trisomy-21 and a $D / D$ translocation replacing two members of the D group. The presumed $\mathrm{D} / \mathrm{D}$ translocation is indicated by an arrow.

TABLE I

SUMMARY OF CHROMOSOME COUNTS OF CULTURED LEUCOCYTES OF MEMBERS OF FAMILY

\begin{tabular}{|c|c|c|c|c|c|c|c|}
\hline & \multicolumn{6}{|c|}{ Chromosome Counts } & \multirow{2}{*}{ Total Cells Counted } \\
\hline & 44 & 45 & 46 & 47 & 48 & 49 & \\
\hline $\begin{array}{l}\text { Propositus } \\
\text { Younger sib } \\
\text { Older sib } \\
\text { Father } \\
\text { Mother }\end{array}$ & $\frac{z}{3}$ & $\begin{array}{r}\overline{-} \\
2 \\
63 \\
2\end{array}$ & $\frac{66}{60}$ & $\begin{array}{l}\bar{Z} \\
\bar{z}\end{array}$ & $\begin{array}{l}\frac{3}{z} \\
=\end{array}$ & $\begin{array}{l}\overline{94} \\
\overline{-}\end{array}$ & $\begin{array}{l}66 \\
97 \\
62 \\
66 \\
66\end{array}$ \\
\hline
\end{tabular}

conjunction with autoradiographic and sex chromatin findings, this karyotype was interpreted as showing an XXXXY sex chromosome constitution, with the autosomes appearing normal. The data obtained from examination of Feulgen-stained buccal smears for sex chromatin are shown in Table II. Of 249 nuclei, $9(3.6 \%)$ were found to have 3 sex chromatin bodies. Of 300 polymorphonuclear cells examined in a Wrightstained blood smear, 8 contained a single drumstick and 2 had double drumsticks. Aliquots of leucocyte cultures were continuously labelled with ${ }^{3} \mathrm{H}$-thymidine (New England Nuclear, specific activity $2 \mathrm{Ci} / \mathrm{mM}$, final concentration $0.2 \mu \mathrm{Ci} / \mathrm{ml}$.) for 4 hours before harvesting to cells labelled late in the $S$ period. Colcemid was added 1 hour before terminating the cultures. After staining with acetic orcein suitable well-spread metaphases were photographed. Autoradiographic stripping film (Kodak AR 10) was applied to the slides in the dark for 4 days before developing. Labelled metaphases were photographed and composite karyotypes were prepared with the aid of photographs taken before the autoradiographic film was applied to the slides. Three heavily labelled X chromosomes were demonstrable in $40 \%$ of the labelled metaphases (Fig. 2).

The father's modal chromosome number was 45 , with only 4 normal members of the $D$ group present. A
TABLE II

NUMBER OF SEX CHROMATIN BODIES FOUND IN BUCCAL SMEAR CELLS OBTAINED FROM YOUNGER SIB

\begin{tabular}{c|c|c|c|c}
\hline 0 & 1 & 2 & 3 & Total Nuclei Counted \\
\hline $\begin{array}{c}187 \\
(75 \cdot 1 \%)\end{array}$ & $\begin{array}{c}33 \\
(13 \cdot 3 \%)\end{array}$ & $\begin{array}{c}20 \\
(8 \%)\end{array}$ & $\begin{array}{c}9 \\
(3 \cdot 6 \%)\end{array}$ & 249 \\
\hline
\end{tabular}

large metacentric chromosome similar to that found in the cells of the propositus was present in place of the 2 missing members of the $D$ group. The karyotype was otherwise normal (Fig. 3).

The karyotypes of the mother and the older sib were normal with a marker satellite in one member of the $D$ group.

The family of the paternal aunt was not available for study. A pedigree is shown in Fig. 4.

\section{Other Studies}

Erythrocyte antigen studies done on the family are summarized in Table III. There were no unexpected findings. Unfortunately, at the time of these studies no $\mathbf{X g}^{\star}$ antiserum was available to test for the presence of this sex-linked antigen. Transferrin, haptoglobin, $\mathrm{Gm}$, and Gc data showed normal inheritance patterns.

The sera of both parents were negative for thyroid antibodies against microsomal and colloidal antigens.

\section{Discussion}

In some of the families in which diverse chromosomal anomalies have been described the findings 
FIG. 2. Metaphase plate of the younger sib labelled with tritiated thymidine and showing 49 chromosomes, including 3 late-replicating $\mathrm{X}$ chromosomes indicated by arrows.

TABQE

RESULTS OF BLOOD GROUP ANTIGEN

\begin{tabular}{|c|c|c|c|c|c|c|c|c|c|c|c|c|c|c|c|c|}
\hline & $\mathrm{ABO}$ & $\mathrm{Rh}:$ & $\begin{array}{l}1 \\
\mathrm{D}\end{array}$ & $\begin{array}{l}2 \\
\mathrm{C}\end{array}$ & $\begin{array}{c}3 \\
E\end{array}$ & $\begin{array}{l}4 \\
c\end{array}$ & $\begin{array}{l}5 \\
\mathrm{e}\end{array}$ & $\begin{array}{c}8 \\
C^{w}\end{array}$ & $\begin{array}{l}10 \\
\mathrm{~V}\end{array}$ & $\begin{array}{l}\text { Probable } \\
\text { Genotype }\end{array}$ & $P_{1}$ & $\mathrm{~K}:$ & $\begin{array}{c}1 \\
\mathrm{~K}\end{array}$ & $\begin{array}{c}3 \\
\mathrm{~K}^{\mathrm{a}}\end{array}$ & $\begin{array}{c}4 \\
K_{p^{b}}\end{array}$ & $\begin{array}{c}6 \\
\mathrm{Js}^{\mathrm{a}}\end{array}$ \\
\hline $\begin{array}{l}\text { Propositus } \\
\text { XXXXY sib } \\
\text { Normal sib } \\
\text { Father } \\
\text { Mother }\end{array}$ & $\begin{array}{l}\mathbf{A}_{1} \\
\mathbf{A}_{1} \\
\mathbf{A}_{2} \\
\mathbf{A}_{2} \\
\mathbf{A}_{1}\end{array}$ & & $\begin{array}{l}+ \\
+ \\
+ \\
+ \\
+\end{array}$ & $\begin{array}{l}\mathbf{0} \\
\mathbf{O} \\
+ \\
+ \\
\mathbf{O}\end{array}$ & $\begin{array}{l}\mathbf{O} \\
\mathbf{O} \\
\mathbf{O} \\
\mathbf{O} \\
\mathbf{O}\end{array}$ & $\begin{array}{l}+ \\
+ \\
+ \\
+ \\
+\end{array}$ & $\begin{array}{l}+ \\
+ \\
+ \\
+ \\
+\end{array}$ & $\begin{array}{l}\mathrm{O} \\
\mathrm{O} \\
\mathrm{O} \\
\mathrm{O} \\
\mathrm{O}\end{array}$ & $\begin{array}{l}\mathrm{O} \\
\mathrm{O} \\
\mathrm{O} \\
\mathrm{O} \\
\mathrm{O}\end{array}$ & $\begin{array}{l}\mathrm{cDe} / \mathrm{cDe} \\
\mathrm{cDe} / \mathrm{cDe} \\
\mathrm{CDe} / \mathrm{cDe} \\
\mathrm{CDe} / \mathrm{cDe} \\
\mathrm{cDe} / \mathrm{cDe}\end{array}$ & $\begin{array}{l}+ \\
+ \\
+ \\
+ \\
+\end{array}$ & & $\begin{array}{l}\mathrm{O} \\
\mathrm{O} \\
\mathrm{O} \\
\mathrm{O} \\
\mathrm{O}\end{array}$ & $\begin{array}{l}\mathbf{O} \\
\mathrm{O} \\
\mathrm{O} \\
\mathrm{O} \\
\mathrm{O}\end{array}$ & $\begin{array}{l}+ \\
+ \\
+ \\
+ \\
+\end{array}$ & $\begin{array}{l}\mathbf{O} \\
\mathbf{O} \\
\mathbf{O} \\
\mathbf{O} \\
\mathbf{O}\end{array}$ \\
\hline
\end{tabular}

XXXXY sib is Gm ( $-3, ? 5)$. Reaction with $\mathrm{Gm}$ (5) system was intermediate. He may not have had the Gm (5) antigen fully developed for comptete inhibition.

Normal sib has no detectable haptoglobin.

Mother has antibody (ab) with Gm (2) system. This antibody was not investigated. 


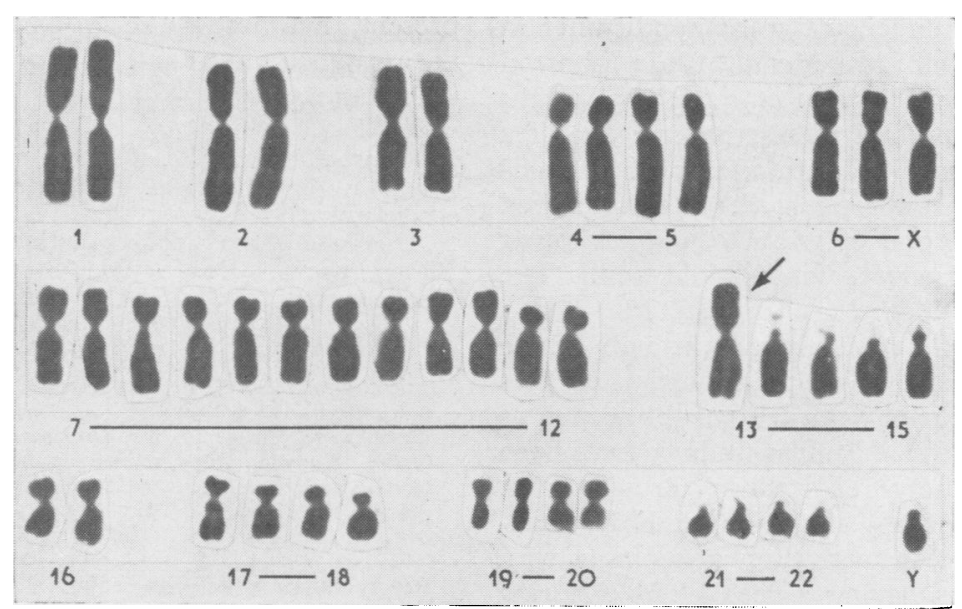

Fig. 3. Karyotype of the father showing the $D / D$ translocation replacing 2 members of the $D$ group. The presumed $D / D$ translocation is indicated by an arrow.

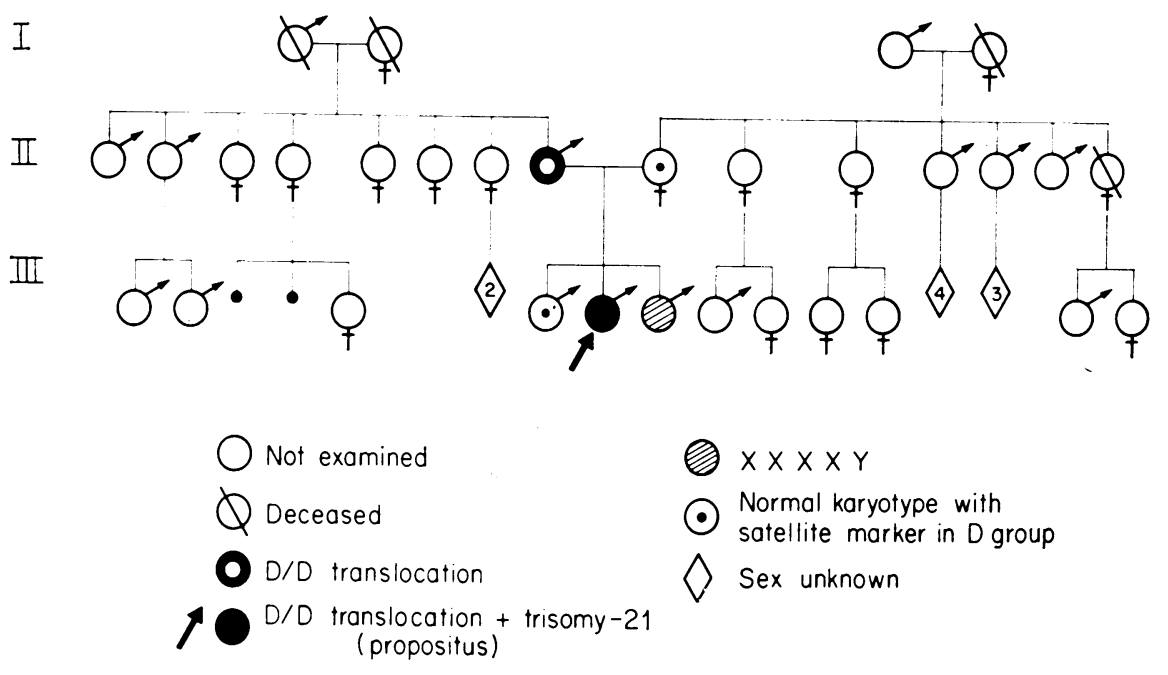

FIG. 4. Family pedigree.

III

AND SERUM PROTEIN STUDIES

\begin{tabular}{|c|c|c|c|c|c|c|c|c|c|c|c|c|c|c|c|c|c|c|}
\hline $\operatorname{Le}^{a}$ & $\mathrm{Le}^{\mathrm{b}}$ & $\mathbf{M}$ & $\mathbf{N}$ & $\mathbf{S}$ & $\mathbf{s}$ & $\mathrm{Lu}^{\mathrm{a}}$ & $\mathrm{Fy}^{2}$ & $\mathbf{J k}^{\mathbf{a}}$ & $\mathrm{Gm}$ & (1) & (2) & (3) & (5) & Inv & (1) & Haptoglobin & Transferrin & Gc \\
\hline $\begin{array}{l}+ \\
\text { Ò } \\
\text { O } \\
\text { O } \\
\text { O }\end{array}$ & $\begin{array}{l}0 \\
0 \\
+ \\
+ \\
0\end{array}$ & $\begin{array}{l}+ \\
+ \\
+ \\
+ \\
+\end{array}$ & $\begin{array}{l}0 \\
+ \\
+ \\
+ \\
0\end{array}$ & $\begin{array}{l}0 \\
+ \\
+ \\
+ \\
+\end{array}$ & $\begin{array}{l}+ \\
+ \\
+ \\
+ \\
+\end{array}$ & $\begin{array}{l}\mathbf{O} \\
\mathrm{O} \\
\mathrm{O} \\
\mathrm{O} \\
\mathrm{O}\end{array}$ & $\begin{array}{l}\mathrm{O} \\
\mathrm{O} \\
\mathrm{O} \\
\mathrm{O} \\
\mathrm{O}\end{array}$ & $\begin{array}{l}+ \\
+ \\
+ \\
+ \\
+\end{array}$ & & $\begin{array}{l}+ \\
+ \\
+ \\
+ \\
+\end{array}$ & $\begin{array}{c}+ \\
+ \\
+ \\
+ \\
+ \\
\mathbf{a b}\end{array}$ & $\begin{array}{l}\mathbf{O} \\
\mathrm{O} \\
\mathrm{O} \\
\mathrm{O} \\
\mathrm{O}\end{array}$ & $\begin{array}{l}+ \\
? \\
+ \\
+ \\
+\end{array}$ & & $\begin{array}{l}0 \\
+ \\
\mathbf{0} \\
+ \\
+\end{array}$ & $\begin{array}{c}2-2 \\
2-2 \\
0 \\
2-2 \\
2-2\end{array}$ & $\begin{array}{l}\mathrm{C}-\mathrm{C} \\
\mathbf{C}-\mathbf{C} \\
\mathbf{C}-\mathbf{C} \\
\mathbf{C}-\mathbf{C} \\
\mathbf{C}-\mathbf{C}\end{array}$ & $\begin{array}{l}1-1 \\
1-1 \\
2-1 \\
2-1 \\
1-1\end{array}$ \\
\hline
\end{tabular}


suggest a familial tendency toward nondisjunction (Hauschka et al., 1962; Miller et al., 1961; Johnston and Petrakis, 1963; Therman et al., 1961; Wright et al., 1963). In other families the presence of a translocation is associated with additional chromosomal anomalies. Hamerton et al. (1963) described a family in which one of two $D / D$ translocation carriers had a trisomy-21 mongoloid son. The family studied by Zergollern et al. (1964) had a D/D translocation transmitted through three generations, with one of the translocation carriers having a mongoloid son with trisomy-21 as well as the $D / D$ translocation. Similar findings have been described in a family reported by Brown et al. (1967). Hustinx (1966) also found a D/D translocation transmitted through three generations with one of the carriers having a mongoloid offspring with trisomy-21 as well as the $D / D$ translocation. Another family studied by Hustinx showed a D/D translocation occurring in a mother who had a daughter with trisomy-21 and an XO sex chromosome constitution. Lejeune et al. (1963) found a 2/22 translocation transmitted over three generations of a family which included a girl with Turner's syndrome and an XO sex chromosome constitution as well as the $2 / 22$ translocation. The simultaneous occurrence of a D/D translocation and an XXY sex chromosome constitution in one patient has been noted by Lejeune, Turpin, and Decourt (1960).

Though chromosome studies of the paternal aunt of the propositus could not be done, the fact that she had two spontaneous abortions suggests that she may be a $\mathrm{D} / \mathrm{D}$ translocation carrier. In the family under discussion, as well as in the published examples, it is possible that non-disjunction may be caused by the presence of a translocation that interferes with normal meiotic pairing. However, the data are biased because of selection of these families, many of them being selected because of the presence of mongolism.

\section{Summary}

A family is described in which the propositus, a trisomy-21 mongoloid boy with a $D / D$ translocation, inherited the D/D translocation from his phenotypically normal father. A sib was found to have an XXXXY sex chromosome constitution. It is possible, though the evidence is inconclusive at present, that there is a relation between the presence $\stackrel{D}{\circ}$ of a translocation and the occurrence of nondisjunction.

We are grateful to Miss Ida Leone and Mrs Charlotte $\overrightarrow{\vec{F}}$

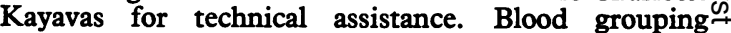
studies were done by Mrs Helen M. Greitzer and Dr. L.O K. Diamond of the Blood Grouping Laboratory, Boston, 흐 Massachusetts. Dr. Sophia Bamford examined the $\overline{\bar{\sigma}}$ blood smears of the XXXXY patient for drumsticks.

\section{REFERENCES}

Barnicot, N. A., Ellis, J. R., and Penrose, L. S. (1963). Translocation and trisomic mongol sibs. Ann. hum. Genet., 26, 279.

Benirschke, K., Brownhill, L., Hoefnagel, D., and Allen, F. H. $\rightarrow$ (1962). Langdon Down anomaly (mongolism) with $21 / 21$ trans- $\vec{\omega}$ location and Klinefelter's syndrome in the same sibship. Cytogenetics, 1, 75 .

Brown, R. K., Burdick, C. O., Malone, H. J., and Wright, Y. M. (1967). Familial D/D translocation associated with trisomy-21. Report of a case with pedigree study. F. Amer. med. Ass., 202, 154. " Gustavson, K.-H., Atkins, L., and Patricks, I. (1964). Diverse chromosomal anomalies in two siblings. Acta paediat. (Uppsala), $53,371$.

Hamerton, J. L., Giannelli, F., and Carter, C. O. (1963). A family 은 showing transmission of a D/D reciprocal translocation and a case of regular 21-trisomic Down's syndrome. Cytogenetics, 2, 194.

Hauschka, T. S., Hasson, J. E., Goldstein, M. N., Koepf, G. F., ワ and Sandberg, A. A. (1962). An XYY man with progeny indicat- $\mathbb{D}$ ing familial tendency to non-disjunction. Amer. F. hum. Genet., (D) 14, 22.

Hustinx, T. W. J. (1966). Cytogenetisch onderzoek bij enige families. Drukkerijuitgeverij Brakkenstein, Nijmegen

Johnston, A. W., and Petrakis, J. K. (1963). Mongolism and Tur- $\vec{C}$ ner's syndrome in the same sibship. Ann. hum. Genet., 26, 407.

Lejeune, J., Lafourcade, J., Salmon, Ch., and Turpin, R. (1963. ๑ Translocation familiale $2 / 22$. Association à un syndrome Turner haplo-X. Ann. Génét., 6, 3.

$\longrightarrow$, Turpin, R., and Decourt, J. (1960). Aberrations chromer somiques et maladies humaines. Syndrôme de Klinefelter XX à 46 chromosomes par fusion centromérique T-T. C.R. Acad. Sci. (Paris), 250, 2468.

Miller, O. J., Breg, W. R., Schmickel, R. D., and Tretter, W. (1961). (T) A family with an XXXXY male, a leukaemic male, and two 21trisomic mongoloid females. Lancet, $2,78$.

Moorhead, P. S., Nowell, P. C., Mellman, W. J., Battips, D. M., and Hungerford, D. A. (1960). Chromosome preparations of leukocytes cultured from human peripheral blood. Exp. Cell Res., 20, 613.

Therman, E., Patau, K., Smith, D. W., and DeMars, R. I. (1961) The $\mathrm{D}$ trisomy syndrome and XO gonadal dysgenesis in two sisters. Amer. F. hum. Genet., 13, 193.

Wright, S. W., Day, R. W., Mosier, H. D., Koons, A., and Mueller, H. (1963). Klinefelter's syndrome, Down's syndrome golism), and twinning in the same sibship. F. Pediat., 62, 217.

Zergollern, L., Hoefnagel, D., Benirschke, K., and Corcoran, P. A. (1964). A patient with trisomy-21 and a reciprocal translocation in the 13-15 group. Cytogenetics, 3, 148.

\section{Addendum}

After submitting this paper it was learned that there was an 11-year-old illegitimate son of the father of the propositus. Cytogenetic studies of this phenotypically normal boy showed a chromosome number of 45 , with a $\mathrm{D} / \mathrm{D}$ translocation. The remainder of the karyotype was normal. 